\title{
Chemical and Geographical Assessment of the Sweetness of the Cultivated Sweetpotato Clones of the World
}

\author{
Stanley J. Kays ${ }^{1}$, Yan Wang, and Wayne J. McLaurin \\ Department of Horticulture, The University of Georgia, Athens, GA 30605-7273 \\ AdDitional INDEX words. Ipomoea batatas, quality, flavor, taste, sugars, sucrose equivalents, breeding, genepool
}

\begin{abstract}
Sweetness, which is known to vary significantly among clones, is the dominant sensory attribute characterizing the flavor of sweetpotatoes [Ipomoea batatas (L.) Lam.]. The relative sweetness of baked roots, expressed as sucrose equivalents, was determined for 272 clones from the U.S. Department of Agriculture National Plant Germplasm System collection. The clones were from 34 countries that collectively produced $93 \%$ of the world's sweetpotato production in 2002. Individual clones were separated into five categories based upon the concentration and relative sweetness of individual sugars, expressed numerically as sucrose equivalents per 100 g dry mass: very high $\geq 38$; high 29-37; moderate 21-28; low 12-20; and nonsweet $\leq 12$. Based upon the mean sucrose equivalents of the clones for each country, only $9 \%$ of the countries, which accounted for only $2.1 \%$ of the total annual production of the countries surveyed, had sweetpotatoes that were classified as very high. While the majority $(62 \%)$ of the countries surveyed had clones that were categorized as high, they represented only $4.4 \%$ of the total production of sweetpotatoes. None of the countries had mean sucrose equivalent values that were categorized as low or nonsweet, although a few individual clones were ranked as low and one as nonsweet. Countries that account for the majority $(87 \%)$ of the sweetpotatoes grown worldwide had a mean sucrose equivalent ranking of moderate. Sweetness is derived from the composite of endogenous sugars (sucrose, glucose, fructose) and maltose formed via starch hydrolysis during baking. Maltose accounted for only $42 \%$ of the average contribution to the total sucrose equivalents. The range in the concentration of individual sugars among clones was substantial as was their contribution to sucrose equivalents. Sucrose equivalents due to maltose in individual clones ranged from 0.6 to 21.9 while endogenous sugars ranged from 6.4 to 46.9 . The results indicate that essentially all of the sweetpotato clones tested from around the world were classified as equal to or greater than moderate in sucrose equivalents, and that there is substantial genetic diversity within the genepool such that the potential exists for tailoring the flavor of new cultivars, via significantly increasing or decreasing sugar content, to meet specific consumer preferences and/or product uses.
\end{abstract}

The sweetpotato is grown in more than 100 countries around the world and ranks fifth as a food crop in developing countries (Food and Agriculture Organization, 2002). Unlike virtually all other staples, the sweetpotato has an extremely dominant, distinct flavor. Flavor is a primary criterion in food selection, and flavor preference for the sweetpotato is known to vary with ethnic background and geographical location (Kays and Horvat, 1983). While used as a staple (i.e., a crop consumed frequently and as a significant portion of the diet) in many countries, it is rarely preferred even though it is more nutritious than most staple crops (Kays and Kays, 1998). The dominance of the flavor greatly minimizes the variation that can be achieved in the final flavor of the cooked product; hence the consistent strong flavor becomes readily tiresome if consumed daily in significant quantities. The sweet taste, due to sugars, is the central feature that significantly modulates the overall flavor through its direct impact on taste but also through the role of monosaccharides as precursors in the synthesis of several key aroma compounds (Kays and Wang, 2000; Wang and Kays, 2000, 2001, 2003).

There is substantial variation in flavor within the sweetpotato genepool (McLaurin and Kays, 1992) and in sweetness due to the endogenous sugars present in the raw roots (sucrose, glucose, and fructose) and the formation of maltose during cooking via the action of $\alpha$-amylase (E.C. 3.2.1.1) and $\beta$-amylase (E.C. 3.2.1.2)

Received for publication 12 Nov. 2004. Accepted for publication 5 Jan. 2005. Acknowledgments. The authors would like to express their appreciation to Don LaBonte and John Bouwkamp for their constructive suggestions.

${ }^{1}$ To whom reprints should be addressed: Department of Horticulture, The University of Georgia, Athens, GA 30602-7273; e-mail: kaysstan@uga.edu
(Morrison et al., 1993; Sistrunk et al., 1954). Because individual sugars vary in their level of sweetness (Shallenberger, 1993) (e.g., fructose is 2.8 times sweeter than maltose), comparisons in the sweetness among clones require both quantification of individual sugars and adjustment for their relative sweetness [i.e., using the sweetness of sucrose as 1 , sucrose equivalents (SE) are calculated]. In addition, not all sugars are equal in flavor quality. In the sweetpotato, the taste of maltose was preferred over the other sugars presented to sensory panelists in the United States (Koehler and Kays, 1991).

The advent of a nonsweet breeding line with the flavor, color, and texture of a white potato (Solanum tuberosum L.) has created the possibility of developing new, uniquely flavored cultivars to expand consumption (Kays et al., 2001). This potential leads to the question of what would constitute an improved flavor(s) for particular target populations of consumers.

To better understand the existing flavor of sweetpotatoes around the world, we determined the sucrose equivalents of clones from a cross-section of countries/protectorates to determine if there are countries or regions that prefer sweetpotatoes with lower/higher levels of sugars.

\section{Methods and Materials}

Clones. Two hundred and seventy-two clones (Table 1) from 34 countries obtained from the U.S. Department of Agriculture (USDA) National Plant Germplasm System (NPGS) repository in Griffin, Ga., were grown at the University of Georgia Horticulture Farm (Athens, Ga.) using standard sweetpotato production prac- 
Table 1. Sweetpotato clones analyzed for sucrose equivalents after baking, listed by country.

\begin{tabular}{|c|c|}
\hline Argentina & 531138 \\
\hline Australia & 508511, 564160 ('Red Abundance'), 573335 ('Cape York'), 585060 \\
\hline Bangladesh & 585065 ('Kamala Sundari’) \\
\hline Brazil & 508513 \\
\hline Costa Rica & 531139,531140 \\
\hline Cuba & 585085 ('Baracutey’), 585086 ('Regional De’), Grif 1068 ('Picadito') \\
\hline Guatemala & $\begin{array}{l}376944 \text { ('Extranjero'), } 376945 \text { ('Morado'), 452267, 508523, 531093, 531094, 531095, 531096, 531097, 531098, 531099, } \\
531101,538306,538307,538308,538309,585077,585078,585079,585092,585093\end{array}$ \\
\hline Honduras & 556934 ('Cuitzeo’) \\
\hline India & 585061 ('Kalmegh S-30’) \\
\hline Indonesia & 585063,585064 \\
\hline Japan & $\begin{array}{l}153905 \text { ('Norin 2'), } 153907 \text { ('Norin 4’), } 153909 \text { ('Taihaku Saitama'), } 508505 \text { ('Kin-toki’), } 508506 \text { ('Koto-puki’), } \\
508508 \text { ('Kogane-sengan'), 508509, } 585087 \text { ('Kyukei’), Grif } 1054\end{array}$ \\
\hline Korea & $\begin{array}{l}585062 \text { ('Suwon 122’), } 585067 \text { ('Okinawa 100’), } 585068 \text { ('Suwon 147’), } 585069 \text { ('Eun-Mi’), } 585070 \text { ('Seon-Mi’), } \\
585071 \text { ('Won-Mi’), } 585072 \text { ('Saing-Mi’), } 585073 \text { ('Pung-Mi’) }\end{array}$ \\
\hline Mexico & 267946, 304088 ('Morado de Yucatan'), 439749, 531136 ('Catemaco'), 585100 ('Tinto'), 585101 \\
\hline Myanmar & $573297,573298,573334$ \\
\hline New Caledonia & 318848 ('Kumala Belep’) \\
\hline New Guinea & $\begin{array}{l}315347,324885,573287,573288,573301,573302,573303,573304,573305,573307,573308,573309, \\
573310 \text { ('Hadare'), } 573311 \text { ('Esdiei'), } 573312 \text { ('Gonime'), } 573313 \text { ('Munduena'), } 573314 \text { ('Naveto'), } \\
573315 \text { ('Ma'Alau'), } 573325,573326 \text { ('Boianai'), 585057, 585058, 564133, 564134, } 564138,564142, \\
564143 \text { ('Amasonto'), } 564144 \text { ('Wanmun small'), 564146 ('Wanmun Kabiufa'), 564149 ('Markham'), } \\
564151 \text { ('Tawa-1'), 564152 ('Talaukwe'), } 564153 \text { ('Mbakoka'), } 564154 \text { ('Keanja', 'Keango'), } 564155 \text { ('Unduandopa'), } \\
564770 \text { ('Wanmum large'), 585105, 585111 ('Merikan') }\end{array}$ \\
\hline New Hebrides & 324886 \\
\hline New Zealand & $286619,286621,308196,308201,320446,320448,286623$ \\
\hline Nigeria & 508522, 531116, 564771, 564773, 585051, Grif 993, Grif 994, Grif 995 \\
\hline Peru & $\begin{array}{l}531121 \text { ('Ihuanco'), } 531131 \text { ('Camote Morado-1'), } 531123 \text { ('Trujillano', 'Huapachero’), } 531151 \text { ('Nino'), } \\
531153 \text { ('Chilingano'), } 531154 \text { ('Negro', 'Corazon de Huarango'), } 531155 \text { ('Pedro Juan'), } 531162 \text { ('Sin Nombre’), } \\
538285 \text { ('Paramutay'), } 538288 \text { ('Eucaru'), } 538292 \text { ('Juancho'), } 538297 \text { ('Amarillo de Chilcalo'), } 538298 \text { ('Wennotz II’), } \\
538300 \text { ('Papino') }\end{array}$ \\
\hline Philippines & 315342 ('Qilin'), 315343, 344124 ('Lakwaw'), 564156, 564157, 564158, 564159, 573333 \\
\hline $\begin{array}{l}\text { People's Republic } \\
\text { of China }\end{array}$ & $286629,308198,508514,508515,508516,508517,508518,508519,508520,508521$ \\
\hline Puerto Rico & $\begin{array}{l}\text { 208796, } 208806,208886,508525 \text { ('Blanquita'), } 538342,538343,538345 \text { ('Macana'), } 538348 \text { ('Viola'), } 538350 \text { ('Francia'), } \\
538351 \text { ('Mojave'), } 538353 \text { ('Amanecer'), } 538354 \text { ('Tapato'), } 556942,564162 \text { ('Margarita') } 573329 \text { ('Wart'), } \\
585109 \text { ('Tapato'), } 585110 \text { ('Papato') }\end{array}$ \\
\hline Ryukyu Islands & 344123 ('Nanyo') \\
\hline Solomon Islands & $573292,573330,585053,585056,564128,564129,564130,538347$ \\
\hline Sri Lanka & 585066 \\
\hline Taiwan & $\begin{array}{l}\text { 531141, 531145, 531146 ('Tainung 65'), } 531147 \text { ('Tainung 57'), 538284, 556940, 556941, 556943 ('Tainan 17'), } \\
\text { 556944, 556945, 556946, 564116, 564117, 564118, 564119, 564120, 585088 ('Tainung 66') }\end{array}$ \\
\hline Thailand & 344120 \\
\hline Timor & $318846,312846-3$ \\
\hline Tonga & $\begin{array}{l}\text { 308200, 564121, } 573316 \text { ('Hawaii’), } 573318 \text { ('Melika'), 573320, 573321, 573322, 585052, } 585054 \text { ('Halasika'), } \\
\quad 585055,585074,585075,585076,585104\end{array}$ \\
\hline United States & 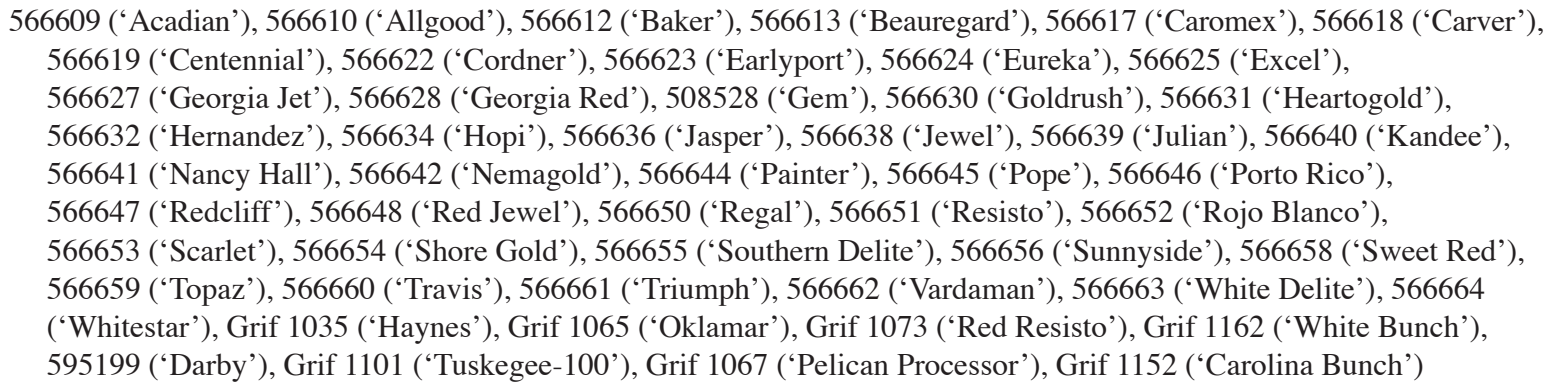 \\
\hline Venezuela & 508530 ('Batata Blanca'), 508531 ('Morada', 'Sombica'), 508532 ('Wiripipi’, 'Itawa') \\
\hline Vietnam & 585059 ('Hung Loc 4’) \\
\hline Western Samoa & $564125,564106,573291,573323,573324,573327,573328$ \\
\hline
\end{tabular}


tices (Granberry et al., 1990). After harvest the roots were cured at $29^{\circ} \mathrm{C}$ and $95 \%$ relative humidity $(\mathrm{RH})$ for $7 \mathrm{~d}$ and stored at 15 ${ }^{\circ} \mathrm{C}$ and $85 \% \mathrm{RH}$ until analysis. Clones are listed by country of origin as indicated by the USDA-NPGS passport data and by their individual plant introduction number (additional information on the clones can be found at USDA, 2005). When available, cultivar names are given in parentheses. The clones tested are diverse, as might be expected, with superior clones having been dispersed widely from their postulated center of origin in northwest South America over the past five centuries (Yen, 1982). During this interval they have been exposed to differing selection pressures for quality attributes by local growers/consumers.

Two nonsweet breeding lines from the University of Georgia (GA90-16, GA90-156) were also analyzed for comparison. Clones were not included when there was an obvious question about their origin (e.g., a clone assigned to a Spanish-speaking country with an Asian cultivar name).

The clones in the USDA-NPGS repository have been collected over a number of years for a wide range of reasons and, consequently, represent a much wider population than the most popular local cultivars currently grown in each location. The assumption we have made is that while the clones included in the test may not be the most popular cultivated for human consumption in each respective country, the mean of the clones from each country gives a general indication of the level of sweetness that is available locally, a relationship undoubtedly strengthened as the number of clones tested per country increases. The cultivars from the United States support this assumption in that the mean for all of the cultivars had the same SE ranking (very high) as two of the most popular cultivars grown at this time (i.e., 'Beauregard' and 'Jewel').

SAMPLE PREPARATION AND BAKING. Cured storage roots of the U.S. \#1 grade or the closest approximation available were used for analysis. The proximal halves of three roots per clone were individually wrapped in aluminum foil, placed in a cold convection oven, and heated to $204^{\circ} \mathrm{C}$ for a total baking time of $75 \mathrm{~min}$. After removal from the oven, a 15 - to 20-g sample of cooked tissue was collected from the fleshy interior to the cambium, composited, freeze dried, and stored at $-30{ }^{\circ} \mathrm{C}$ until analysis.

ExTraction OF SUGARs. The freeze-dried samples were milled into flour using a Cyclotec 1093 sample mill (Rose Scientific Ltd., Edmonton, Alberta, Canada). A total of $100 \mathrm{mg}$ of flour was homogenized in $10 \mathrm{~mL}$ of $80 \%$ methanol containing 2.2 mg phenyl- $\beta$-D-glucopyranose as an internal standard for $1 \mathrm{~min}$ at 17,000 rpm using a Handishear AC hand-held homogenizer (Virtis, Gardiner, N.Y.). The resulting slurry was centrifuged 5 min at $17,000 g_{n}$. Ten milliliters of supernatant was pipetted into a vial and stored at $4{ }^{\circ} \mathrm{C}$ until analysis.

DERIVATIZATION. Extracts were prepared via oximetrimethylsilyl derivatization according to Chapman and Horvat (1989) with minor modification. Fifty microliters of sample was pipetted into a vial, placed on a heating block at $40{ }^{\circ} \mathrm{C}$, and dried with nitrogen gas. Twentyfive microliters of hydroxylamine- $\mathrm{HCl}\left(25 \mathrm{mg} \cdot \mathrm{mL}^{-1}\right.$ in pyridine) was added to each vial and heated at $75^{\circ} \mathrm{C}$ for $30 \mathrm{~min}$. The oximes of sugars were then derivatized by injecting $70 \mu \mathrm{L} \mathrm{BSTFA}+1 \%$ TMCS and heated at $75^{\circ} \mathrm{C}$ for $20 \mathrm{~min}$. After cooling, a $1 \mu \mathrm{L}$ injection was made into the gas chromatograph using an autoinjector. A mixture containing known amounts of the internal standard and pure reference sugars (fructose, galactose, glucose, inositol, sucrose, maltose) was analyzed every
10 samples to obtain correction factors.

Gas Chromatography. Chromatography analyses were performed using a Hewlett-Packard 5890A gas chromatograph (Agilent, Palo Alto, Calif.) equipped with a flame ionization detector. The GC column was a $30 \mathrm{~m} \times 0.32 \mathrm{~mm}$ (i.d.) fused silica, DB-5, $0.25 \mu \mathrm{L}$ film thickness capillary column (J\&W Scientific, Folsom, Calif.). Injector and detector temperatures were 250 and $300{ }^{\circ} \mathrm{C}$, respectively. Oven temperature was initially held at $150{ }^{\circ} \mathrm{C}$ for $1 \mathrm{~min}$ and then programmed from 150 to $210{ }^{\circ} \mathrm{C}$ at $4{ }^{\circ} \mathrm{C} \cdot \mathrm{min}^{-1}$ and held at $210{ }^{\circ} \mathrm{C}$ for $30 \mathrm{~s}$ and then to $250{ }^{\circ} \mathrm{C}$ at $7{ }^{\circ} \mathrm{C} \cdot \mathrm{min}^{-1}$ and held at $250{ }^{\circ} \mathrm{C}$ for $30 \mathrm{~s}$ and finally to $280{ }^{\circ} \mathrm{C}$ at $4{ }^{\circ} \mathrm{C} \cdot \mathrm{min}^{-1}$ and held for $5 \mathrm{~min}$. Helium was used as the carrier gas at a flow rate of $53 \mathrm{~mL} \cdot \mathrm{min}^{-1}$. The splitless injection mode was used. Air and hydrogen flow rates to the detector were $370-380 \mathrm{~mL} \cdot \mathrm{min}^{-1}$ and $28 \mathrm{~mL} \cdot \mathrm{min}^{-1}$, respectively. Nitrogen was used as a make-up gas at a flow rate of $30 \mathrm{~mL} \cdot \mathrm{min}^{-1}$. An HP 3392A integrator was connected to the GC for peak area determination. Identification of each sugar was based upon retention times using authentic standards and by adding standards to samples before extraction to verify retention times of individual peaks. Recovery tests were carried out using standard addition methods. The technique was found to be quantitative (i.e., $>96 \%$ recovery). Standards for sugars exhibited less than $3 \% \mathrm{CV}$ among triplicate injections of the same sample.

Calculation of sucrose equivalents. Because individual sugars vary in their sweetness, to obtain a relative measure of sweetness that would allow for comparison among clones, sucrose equivalents (SE) were calculated using the equation: sucrose equivalents $=1.2$ fructose +1 sucrose +0.64 glucose +0.43 maltose (Shallenberger, 1993) and were expressed as grams per $100 \mathrm{~g}$ dry mass (DM). An SE of $30 \mathrm{~g} / 100 \mathrm{~g}$ DM indicates that the combined sweetness of the sugars present is equal to that of $30 \mathrm{~g}$ sucrose/100 g DM. Galactose and inositol were not included due to their relatively low sweetness and extremely low concentrations. Clones were separated into five sucrose equivalent categories based on sensory panelist assessments of the threshold for the very high ( $\mathrm{SE} \geq 38 \mathrm{~g} / 100 \mathrm{~g} \mathrm{DM})$ and nonsweet $(\mathrm{SE} \leq 12 \mathrm{~g} / 100$ g DM) categories. Three individual categories (high, moderate, low) were assigned in comparable increments between the very high and nonsweet catagories (Table 2). Previously we utilized four categories in screening germplasm; however, since taste panels can discriminate between relatively small increments in sweetness (Koehler and Kays, 1991), an additional category was added for increased precision.

Sucrose equivalents were also calculated for endogenous sugars (sucrose, fructose, and glucose) vs. sugar derived from baking (maltose) to assess the relative contribution of each.
Table 2. Categories based on sucrose equivalents (SE), number of clones per category, percentage of countries surveyed per category, and percentage of annual total production of countries surveyed per category (Food and Agriculture Organization, 2002).

\begin{tabular}{lcccc}
\hline & $\begin{array}{c}\text { SE } \\
\text { (g per 100 g } \\
\text { dry mass) }\end{array}$ & $\begin{array}{c}\text { Clones } \\
\text { (no. per } \\
\text { category) }\end{array}$ & $\begin{array}{c}\text { Proportion in } \\
\text { countries } \\
\text { surveyed } \\
\text { (\% per category) }\end{array}$ & $\begin{array}{c}\text { Proportion of } \\
\text { annual } \\
\text { production } \\
\text { (\% per category) }\end{array}$ \\
\hline Nonsweet & $\leq 12$ & 1 & 0 & 0 \\
Low & $13-20$ & 7 & 0 & 0 \\
Moderate & $21-28$ & 91 & 29 & 93.5 \\
High & $29-37$ & 124 & 62 & 4.4 \\
Very high & $\geq 38$ & 49 & 9 & 2.1 \\
\hline
\end{tabular}




\section{Results and Discussion}

Five SE categories were established for baked sweetpotatoes based upon the range in sugars found within the germplasm assessed (Table 2). The majority of the clones (124) were in the high SE category (29-37 g/100 g DM). The second greatest number (91) were classified as moderate followed by very high (49). Only seven clones were low and one was nonsweet. Several nonsweet clones have been reported (e.g., GA90-16 is potato-like in flavor and has a SE value of only $11.3 \mathrm{~g} / 100 \mathrm{~g} \mathrm{DM}$ ) (Kays et al., 2001). The SE of individual clones ranged from 12 to $56 \mathrm{~g} / 100 \mathrm{~g} \mathrm{DM}$. It should be noted that in addition to a genetic component, the sugar content and sucrose equivalents of the cooked product is also a function of the method of cooking (Sun et al., 1994), which in turn impacts the product's aroma and overall flavor (Wang and Kays, 2001). Test samples were baked in a convection oven, which gives substantially higher SE values than, for example, microwave cooking (Sun et al., 1994), due to the increased starch hydrolysis and maltose formation.

A mean SE value was calculated for the clones from each country (Table 3 ) to obtain a general estimate of the typical sugar level to which consumers have access. Numerically the majority of the countries had clones that were classified as having high SE. The second largest number of countries had clones with a mean classification of moderate. Only three countries had mean values in the very high category (i.e., Bangladesh, Indonesia, U.S.). Of the countries in which sweetpotato clones were assessed, 29.4\% of the countries had mean values within the moderate category, $61.8 \%$ high, and $8.8 \%$ very high (Table 2 ). In a few instances a country's classification is based on a very small number of clones and may, therefore, not give a good estimate of the SE level available to the consumers there.

The geographical distribution of the clones by countries, expressed as the mean SE value, did not present a distinct pattern (Fig. 1). Countries in which the mean SE value for the clones was classified as moderate were found in South America, Asia, the Caribbean, and Melanesia. Likewise, countries with a mean SE ranking of very high were also relatively widely dispersed (i.e., U.S., Bangladesh, Indonesia). Based upon the clones surveyed, there did not appear to be a geographical region in which one level of SE is preferred over another; rather, essentially all of the sweetpotatoes are relatively sweet (i.e., $\geq$ moderate SE).

The countries from which clones were tested produced $93 \%$ of the world's sweetpotatoes in 2002 (Table 3). When SE categories were assessed relative to the annual production, countries that had a mean classification of high, which represented the greatest number of countries, comprised only $2.1 \%$ of the total production of the countries tested (Table 2). The majority of the sweetpotatoes $(93.2 \%)$ was classed as moderate, and $4.4 \%$ were very high. Therefore, while $62 \%$ of the countries surveyed had sweetpotatoes categorized as high, the majority of the sweetpotatoes produced in the countries surveyed were classified as moderate, one category lower. Assessing the percentage of the world's total production that fell into the various sweetness categories was strongly influenced by China, the world's leading producer of the crop (Food and Agriculture Organization, 2002). While the mean SE category for the Chinese clones tested was moderate, a significant portion of the sweetpotatoes grown there are processed to starch, during which the water-soluble mono- and disaccharides are lost. SE level, therefore, is not a critical selection trait and as a consequence, the presence of starch types in the clones tested could bias the mean toward a
Table 3. Countries ranked by the mean ${ }^{z}$ sucrose equivalents (SE) of baked sweetpotato clones within sucrose equivalent categories (see Table 2), with production statistics by country for 2001 (Food and Agriculture Organization, 2002).

\begin{tabular}{|c|c|c|}
\hline $\begin{array}{l}\text { Sucrose equivalent } \\
\text { category and country }\end{array}$ & $\begin{array}{c}\text { Mean SE } \\
\text { g per } 100 \text { g dry mass }\end{array}$ & $\begin{array}{c}\text { Production } \\
(\mathrm{kt})\end{array}$ \\
\hline \multicolumn{3}{|l|}{ Very high } \\
\hline Bangladesh & 49.2 & 346 \\
\hline Indonesia & 44.8 & 1746 \\
\hline United States & 37.9 & 567 \\
\hline Total & & 2659 \\
\hline \multicolumn{3}{|l|}{$\underline{\text { High }}$} \\
\hline Philippines & 36.5 & 549 \\
\hline New Caledonia & 36.0 & 3 \\
\hline Venezuela & 34.8 & 12 \\
\hline Vietnam & 34.4 & 1725 \\
\hline Australia & 34.1 & 6 \\
\hline Mexico & 33.2 & 60 \\
\hline Timor & 31.3 & --- \\
\hline Costa Rica & 32.8 & --- \\
\hline Puerto Rico & 32.8 & 2 \\
\hline New Zealand & 32.0 & 16 \\
\hline Guatemala & 30.9 & --- \\
\hline Solomon Islands & 30.9 & 84 \\
\hline Nigeria & 30.4 & 2503 \\
\hline Western Samoa & 30.3 & --- \\
\hline Taiwan & 30.3 & --- \\
\hline Tonga & 30.0 & 6 \\
\hline Peru & 29.6 & 224 \\
\hline Myanmar & 29.5 & 57 \\
\hline Korea & 29.5 & 250 \\
\hline Ryukyu Islands & 29.3 & --- \\
\hline Sri Lanka & 29.2 & 49 \\
\hline Total & & 5546 \\
\hline \multicolumn{3}{|l|}{ Moderate } \\
\hline Japan & 28.7 & 1030 \\
\hline Brazil & 28.7 & 483 \\
\hline Papua New Guinea & 27.7 & 490 \\
\hline New Hebrides & 27.6 & --- \\
\hline Argentina & 27.4 & 310 \\
\hline India & 27.2 & 1200 \\
\hline Cuba & 27.0 & 270 \\
\hline Honduras & 26.4 & 2 \\
\hline $\begin{array}{l}\text { People's Republic } \\
\text { of China }\end{array}$ & 25.4 & 114289 \\
\hline Thailand & 23.2 & 97 \\
\hline Total & & 118171 \\
\hline$\underline{\text { Low }}$ & $---y$ & \\
\hline Nonsweet & $---y$ & \\
\hline
\end{tabular}

${ }^{\mathrm{z}}$ Means represent the average SE of all clones tested within a country. yNone of the countries had clones with an average SE in this category.

lower average SE value. Relatively sweet baked sweetpotatoes, purchased from street venders in Bejing and Qufu in Fall 2000, appeared to be preferred as a snack food over less sweet cultivars (personal observation).

The majority of the clones from the U.S. that have been released as named cultivars were classified either as high or very high in SE. The U.S. cultivars were also grouped (Table 4) by the state in which they were released to determine if a pattern 


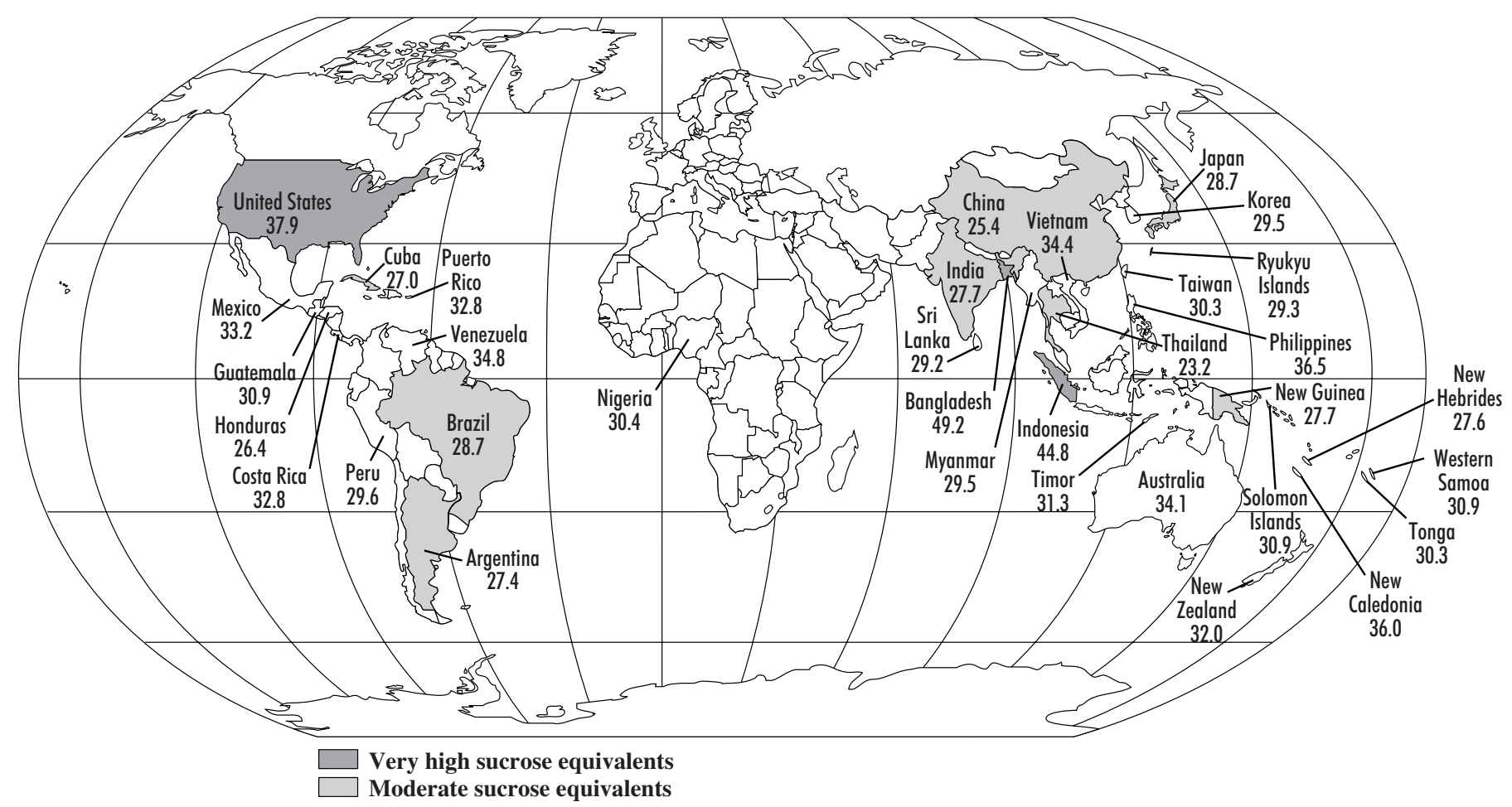

Fig. 1. Geographical distribution of the sucrose equivalents (SE) of baked sweetpotato storage roots of clones from 34 countries, expressed as the mean SE of the clones from each country. Countries in which the clonal means were categorized very high and moderate SE are highlighted.

indicative of the importance of sweetness in the selection criteria could be ascertained. Oklahoma and Louisiana had the highest mean SE values for the cultivars developed. In general, all of the states that had relatively large sweetpotato breeding programs consistently had cultivars that were in the high to very high catagories.

The distribution of SE was plotted as SE derived from the hydrolysis of starch during baking vs. total SE (endogenous sugars + maltose) with the figure separated into the five SEcategories (Fig. 2). The majority of the clones cluster in the high to moderate categories. Relatively few were found in the low and nonsweet categories, indicating that either the clones assessed were selected for sugar content or that the lack of sugars is a trait that seldom emerges in cultivars selected. Figure 3 illustrates the relationship between SE derived from maltose and SE from the endogenous sugars
Table 4. Sucrose equivalents (SE) of U.S. cultivars by state of origin and mean per state.

\begin{tabular}{|c|c|c|c|c|c|}
\hline $\begin{array}{l}\text { State of origin } \\
\text { of cultivar }\end{array}$ & $\begin{array}{c}\text { SE (g per } \\
100 \text { g dry mass) }\end{array}$ & $\begin{array}{l}\text { State of origin } \\
\text { of cultivar }\end{array}$ & $\begin{array}{c}\text { SE (g per } \\
100 \text { g dry mass) }\end{array}$ & $\begin{array}{l}\text { State of origin } \\
\text { of cultivar }\end{array}$ & $\begin{array}{c}\text { SE (g per } \\
100 \text { g dry mass) }\end{array}$ \\
\hline Alabama & & Maryland & & South Carolina & \\
\hline Carver & 40.3 & Sunnyside & 35.6 & Excel $^{u}$ & 36.3 \\
\hline Rijo Blanco & $\underline{25.5}$ & Whitestary & $\underline{25.3}$ & Redcliff & 42.6 \\
\hline$\overline{\mathrm{x}}$ & 32.8 & $\bar{x}$ & 30.5 & Regalu $^{u}$ & 40.5 \\
\hline Georgia & & Mississippi & & Resisto $^{u}$ & 34.7 \\
\hline Coastal Red & 36.6 & Verdaman & 24.6 & Southern Delite & $\underline{37.2}$ \\
\hline Georgia Jet & $\underline{40.0}$ & North Carolina & & $\bar{x}$ & 38.3 \\
\hline$\overline{\mathrm{x}}$ & 38.3 & Caromex ${ }^{x}$ & 34.1 & Texas & \\
\hline Kansas & & Gem & 35.7 & Topaz & 31.1 \\
\hline Kandee & 38.0 & Jewel & 42.8 & Virginia & \\
\hline Lousiana & & Pope & 41.8 & Painter & 35.7 \\
\hline Arcadian & 46.7 & Red Jewel & 37.9 & Shore Gold & $\underline{38.7}$ \\
\hline Beauregard & 43.5 & Scarlet & 40.1 & $\overline{\mathrm{x}}$ & 37.2 \\
\hline Centennial & 38.2 & Sweet Red & 30.8 & Released jointly & \\
\hline
\end{tabular}

Darby $\quad 47.2$

Eureka $^{z} \quad 35.7$

Goldrush $\quad 46.3$

Heartogold $\quad 47.9$

Hernandez $\quad 41.5$

Jasper $\quad 42.8$

Julian $\quad 38.3$

Travis $\quad \underline{42.7}$

$\overline{\mathrm{x}} \quad \overline{42.8}$

White Delite $\quad \underline{32.4}$

$\overline{\mathrm{x}} \quad 37.0$

New Mexico Hopiw

Oklahoma

Allgold

Nemagold

Oklamar

Cordnerv

$$
\overline{\mathrm{x}}
$$

47.5

33.9

52.5

$\underline{38.4}$

43.1
Released jointly by:

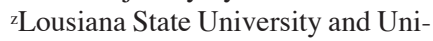
versity of California-Davis.

yUSDA-Beltsville and the University of Maryland.

xNorth Carolina State University and New Mexico State University. wUSDA Mississippi State University and New Mexico State University.

voklahoma State University and Texas A\&M University.

uUSDA Charleston and Clemson University. 


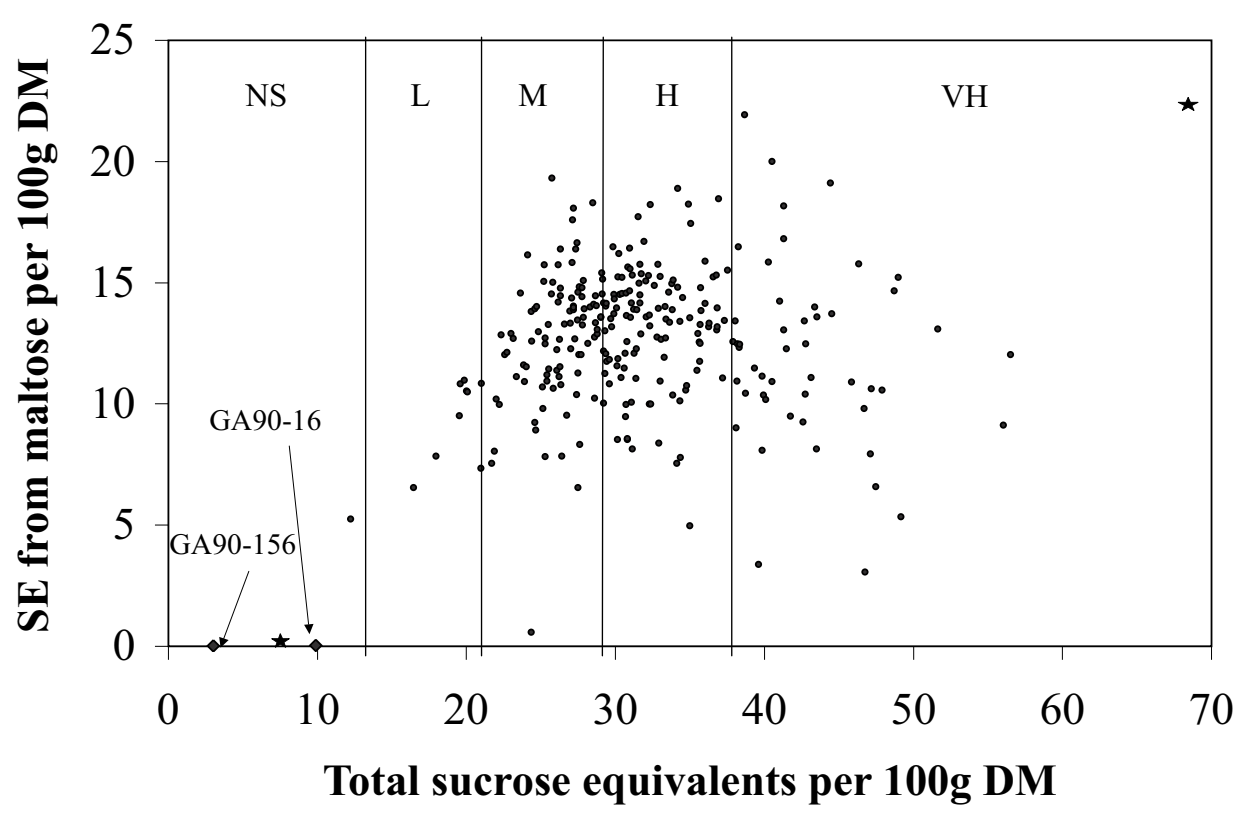

Fig. 2. Total sucrose equivalents (SE) in grams per $100 \mathrm{~g}$ dry mass (DM) of baked sweetpotato storage roots from various countries plotted against SE derived from maltose and separated into the SE categories presented in Table 2 (NS = nonsweet, $\mathrm{L}=$ low, $\mathrm{M}=$ moderate, $\mathrm{H}=$ high, $\mathrm{VH}=$ very high). Stars $(\star)$ indicate the position of the maximum and minimum SE levels that could theoretically be attained if a clone possessed the highest and lowest maltose and endogenous sugar values in the current study. Diamonds $(\diamond)$ indicate the position of two nonsweet breeding lines developed at the University of Georgia.

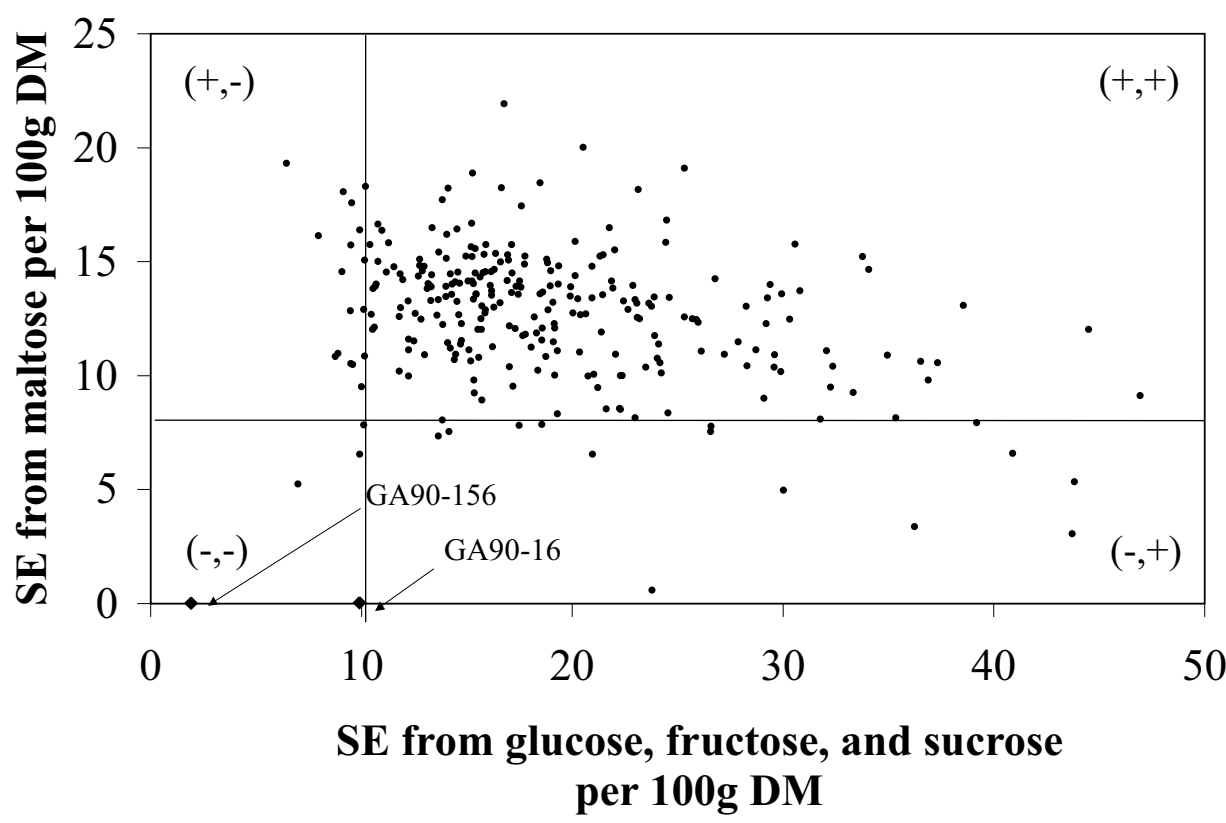

Fig. 3. Distribution of the sucrose equivalents (SE) in grams per $100 \mathrm{~g}$ dry mass (DM) of baked sweetpotato clones from various countries plotted as SE derived from maltose formed during cooking vs. SE derived from endogenous sugars (glucose, fructose, and sucrose). The clones are separated into four categories [low sugars/low starch hydrolysis (-/-); low sugars/high starch hydrolysis $(-/+)$; high sugars/low starch hydrolysis (+/-); and high sugars/high starch hydrolysis $(+/+)$ ] based upon the level of hydrolysis of starch during cooking and the level of endogenous sugars present in the roots (Morrison et al., 1993). Diamonds ( ) indicate the position of two nonsweet breeding lines developed at the University of Georgia. (i.e., sugar formed during cooking vs. sugars present prior to cooking). Endogenous sugars comprised a higher average percentage of the total SE across all clones (58\%) than did maltose $(42 \%)$; the former ranging from $25 \%$ to $98 \%$ and the latter $2 \%$ to $75 \%$. The average percentage of the SE value across all clones contributed by each sugar was: sucrose $44 \%$, fructose $8 \%$, glucose $6 \%$, and maltose $42 \%$; and the range: sucrose $6 \%$ to $77 \%$, fructose $1 \%$ to $36 \%$, glucose $0 \%$ to $23 \%$, and maltose $2 \%$ to $75 \%$. It had been previously proposed (Morrison et al., 1993) that sweetpotato germplasm could be separated into four general classes based on initial sugar concentration and changes during cooking: 1) low sugars/low starch hydrolysis $(-/-)$; 2) low sugars/high starch hydrolysis $(-/+)$; 3) high sugars/low starch hydrolysis (+/-); and 4) high sugars/high starch hydrolysis $(+/+)$. Only one clone in the collection surveyed fell into the-/-classification, indicating decidedly nonsweet clones either seldom occur or are routinely discarded. Likewise, a relatively small number of clones were found in the $-/+$ and $+/$ - categories with the majority classified as $+/+$ (Fig. 3).

The contribution of maltose ranged in SE from 0.58 to $21.92 \mathrm{~g} / 100 \mathrm{~g}$ DM while the contribution from the endogenous sugars ranged from 6.44 to $46.94 \mathrm{~g} / 100 \mathrm{~g} \mathrm{DM}$. This indicates that it may be possible to select for cultivars with distinctly higher SE than the highest existing clones if exceptionally high maltose formation potential can be combined with high endogenous sugars [e.g., potentially giving a total SE of approximately 69 or $19 \%$ higher than the highest clone tested (Fig. 2)]. Such a combination assumes that there would be no fatal deficits (e.g., yield, storage disease susceptibility) that would eliminate such clones. Likewise, it may also be possible to select clones that are exceptionally nonsweet [e.g., approximately $7 \mathrm{SE}$ (Fig. 2)] for uses in which they would be advantageous. One mechanism conferring a low SE value involves the gene for $\beta$-amylase (Kumagai et al., 1990) in which a functional gene product does not appear to be formed. It is controlled by one recessive allele ( $\beta$-amy) that appears in a reasonably high frequency. Plotted on Fig. $3(\diamond)$ are two nonsweet breed- 
ing lines selected at the University of Georgia, indicating that exceptionally nonsweet cultivars are readily attainable. The fact that more nonsweet cultivars were not in the samples tested and presumably not among the cultivars utilized around the world, could be due to several possible reasons: 1) the nonsweet trait(s) is seldom present in breeding populations; 2) the population of clones in the U.S. germplasm collection is biased toward sweet clones; or 3 ) the nonsweet trait occurs but the clones are discarded as unacceptable.

Increasing or decreasing sweetness in future clones involves altering two groups of genes: genes controlling the formation of starch, which influences latent pools of mono- and disaccharides within the storage roots, and genes controlling starch hydrolysis and maltose formation. Existing evidence from the germplasm surveyed indicates that there is sufficient variation in both traits present to allow significant increases or decreases in sweetness.

Evidence presented indicates that sweetpotatoes grown worldwide are all moderate to high in their SE values. Clones are present within the genepool that will allow selecting new cultivars that are significantly higher or lower in SE than existing cultivars. Due to the dominance and importance of sweetness in the overall flavor of the cooked product, the potential exists for tailoring the flavor for specific consumer preferences and product uses, increasing the utilization of the crop worldwide.

\section{Literature Cited}

Chapman, G.W., Jr. and R.J. Horvat. 1989. Determination of nonvolatile acids and sugars from fruits and sweet potato extracts by capillary GLC and GLC/MS. J. Agr. Food Chem. 37:947-950.

Food and Agriculture Organization. 2002. FAO production yearbook. Vol 56. Food and Agr. Org. United Nations, Rome.

Granberry, D.M., W.J. McLaurin, and W.O. Chance. 1990. Sweetpotato, commercial vegetable production. Univ. of Georgia Coop. Ext. Serv. Bul. 677.

Kays, S.J. and R.J. Horvat. 1983. A comparison of the volatile constituents and sugars of representative Asian, Central American and North American sweet potatoes, p. 577-586. Sixth Intl. Symp. on Trop. Root Crops, Lima, Peru.
Kays, S.J. and S.E. Kays. 1998. Sweetpotato chemistry in relation to health, p. 231-272. Sweetpotato production systems toward the 21st century. Kyushu National Agr. Expt. Sta., Miyakonojo, Miyazaki, Japan.

Kays, S.J., W.J. McLaurin, Y. Wang, P.D. Dukes, J.R. Bohac, and D.M. Jackson. 2001. GA90-16-Anonsweet, staple-type sweetpotato breeding line. HortScience 36:175-177.

Kays, S.J. and Y. Wang. 2000. Thermally induced flavor compounds. HortScience 35:1002-1012.

Kumagai, T., Y. Umemura, T. Baba, and M. Iwanaga. 1990. The inheritance of $\beta$-amylase null in storage roots of sweet potato Ipomoea batatas (L.) Lam. Theor. Appl. Genet. 79:369-376.

Koehler, P.E. and S.J. Kays. 1991. Sweet potato flavor. Quantitative and qualitative assessment of optimum sweetness. J. Food Quality 14:241-249.

McLaurin, W.J. and S.J. Kays. 1992. Genetic diversity in sweetpotato flavor, p. 420-427. The sweetpotato in the 21st century. Second Intl. Symp. Sweetpotato, Montgomery, Ala.

Morrison, T.A., R. Pressey, and S.J. Kays. 1993. Changes in $\alpha$ - and $\beta$-amylase activities during storage of sweetpotato lines with varying starch hydrolysis potential. J. Amer. Soc. Hort. Sci. 118:236-242.

Shallenberger, R.S. 1993. Taste chemistry. Blackie Academic, London.

Sistrunk, W.A., J.C. Miller, and L.G. Jones. 1954. Carbohydrate changes during storage and cooking of sweet potato. Food Technol. 8:223-226.

Sun, J.-B., R.F. Severson, and S.J. Kays. 1994. Effect of heating temperature and microwave pretreatment on the formation of sugars and volatiles in Jewel sweetpotato. J. Food Quality 17:447-456.

U.S. Dept. of Agriculture. 2005. Data from GRIN taxonomy. USDA, Agriculture Research Service. 5 Jan. 2005. <www.ars-grin.gov/cgibin/npgs.html/tax_search.pl?Ipomoea+batatas $>$.

Wang, Y. and S.J. Kays. 2000. Contribution of volatile compounds to the characteristic aroma of baked 'Jewel' sweetpotatoes [Ipomoea batatas (L.) Lam.]. J. Amer. Soc. Hort. Sci. 125:638-643.

Wang, Y. and S.J. Kays. 2001. Effect of cooking method on the aroma constituents of sweetpotatoes [Ipomoea batatas (L.) Lam.]. J. Food Quality 24:67-78.

Wang, Y. and S.J. Kays. 2003. Analytically directed flavor selection in breeding food crops. J. Amer. Soc. Hort. Sci. 128:711-720.

Yen, D.E. 1982. Sweet potato in historical perspective, p. 17-30. Proc. First Intl. Symp. Sweet Potato, Asian Vegetable Res. and Dev. Ctr., Shanhua, Taiwan. 